\title{
Historical perspective of climate change in sustainable livelihoods of coastal areas of the Red River Delta, Nam Dinh, Vietnam
}

\author{
Thi Kieu Van Tran, Ehsan Elahi, Liqin Zhang, Habibullah Magsi, \\ Quang Trung Pham and Tuan Minh Hoang \\ (Author affiliations can be found at the end of the article)
}

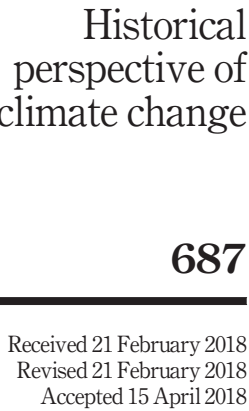

\begin{abstract}
Purpose - The purpose of this paper is to estimate a recent trend in climate change and its impact on livelihood of community living in Nam Dinh province, Vietnam. Further, it aims to increase the government attention for adaptation measures by providing awareness of climate change and its negative impacts on livelihood.

Design/methodology/approach - For study purpose, cross-sectional and secondary data sets were used. The community perceptions about climate change were recorded by face-to-face interviews of 500 respondents from Nam Dinh province, Vietnam in April 2015 by using a well-structured questionnaire, whereas secondary data were collected from the statistical yearbook of General Statistics Office of Vietnam. To accomplish the study objectives, Cobb-Douglas production function and Likert scale were used to estimate the community perceptions of climate change and impact of climate change on livelihood, respectively.

Findings - Results depict that climate change negatively impacted on the productivity of rice and livestock. Particularly, frequently occurring of droughts, floods and salinity intrusion negatively impacted on rice productivity, while livestock productivity is decreased by frequent occurring of flood storms in study area.

Originality/value - The study results suggest a government support is essential to achieve sustainable livelihoods for coastal communities living in the Red River Delta, particularly some adaptation measures in the context of climate change are required in study area.
\end{abstract}

Keywords Vietnam, Livelihoods, Climate change, Extreme weather, Typhoons

Paper type Research paper

(C) Thi Kieu Van Tran, Ehsan Elahi, Liqin Zhang, Habibullah Magsi, Quang Trung Pham and Tuan Minh Hoang. Published by Emerald Publishing Limited. This article is published under the Creative Commons Attribution (CC BY 4.0) licence. Anyone may reproduce, distribute, translate and create derivative works of this article (for both commercial \& non-commercial purposes), subject to full attribution to the original publication and authors. The full terms of this licence may be seen at http:// creativecommons.org/licences/by/4.0/legalcode

This paper forms part of a special section "Climate change and arid land agriculture: impact and adaptive”, guest edited by Mirza Barjees Baig, Gary S. Stradquadine, Joel L. Cuello and Mahmoud E1 Solh.

The authors are grateful to the Chinese Scholarship Council (CSC) (CSC No. 2012GXZ551), China Agricultural University, Central Institute for Economic Management of Vietnam and the Startup Foundation for Introducing Talent of Nanjing University of Information Science and Technology (No. 2017r101) for fellowship and financial support for this study. The authors would like to acknowledge to Munawar Hassan: Department of Economics and Management, China Agricultural University, Beijing, China for his thoroughly revised paper for correction of English and technical errors.

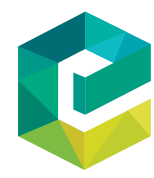

International Journal of Climate Change Strategies and Management
Vol. 11 No. 5, 2019 pp. 687-695 
IJCCSM 11,5

\section{8}

\section{Introduction}

The recent trend of climate changed caused social vulnerability and unsustainability in agriculture system of Vietnam (Kelly and Adger, 2000; Vien, 2011). A sustainable livelihood is a key to social well-being, development and poverty reduction (Allison and Horemans, 2006). The coastal zones of Vietnam affected severely by natural disasters (Noy and Vu, 2010) and adaptation are the key to reduce vulnerability and enhancing resilience to climate change in coastal communities (Adger et al., 2005). Rising sea levels, temperatures and extreme weather events restaurant in a serious damage to the livelihood of local communities and economy of Vietnam (Wassmann et al., 2004). The climate change in Red River Delta and Mekong Delta is more than a serious threat for Vietnam because all livelihood activities at Red River Delta and Mekong Delta contribute more than one-third to the economy of Vietnam (Chaudhry and Ruysschaert, 2007).

\subsection{Evidence of climate change in Vietnam}

Located in the tropical monsoon region of Southeast Asia (Cai et al., 2018), Vietnam is suffering adversely from impacts of the extreme climate change, including typhoons, tropical storms and extreme weather events (Kleinen, 2007). In addition to experiencing abnormal weather impacts, Vietnam also suffered from other long-term hazards as drought, floods, rise in sea level and saltwater infiltration which greatly affect agricultural and aquaculture livelihoods (Hanh and Furukawa, 2007; Vien, 2011). According to recent estimates, a 1 per cent loss in Vitnmas' GDP in 2015 was estimated due to natural disasters, particularly typhoons, floods and landslides (Navrud et al., 2012; Arouri et al., 2015). Climate change is becoming increasingly prominent in Vietnam (Huong and Pathirana, 2013). In the past 50 years, the average annual temperature in Vietnam has increased by $2-3^{\circ} \mathrm{C}$ (GuhaSapir et al., 2004). Moreover, a strange and reverse phenomenon has been occurring in Vietnam, specifically in winter; the temperature tends to be higher than the summer and the temperature in the Northern region increases faster than South (Nguyen et al., 2014). In Hon Dau station, sea level rises on average about $3 \mathrm{~mm}$ per year which means it has increased approximately $20 \mathrm{~cm}$ in the past 50 years (Guha-Sapir et al., 2004). In addition to the increase in temperature and sea level, the average rainfall in the past five decades has decreased by about 2 per cent per year in overall Vietnam (Guha-Sapir et al., 2004). There are more extreme weather events, especially intense storms, late-ending storms, very cold weather and prolonged damaging cold intervals (Mai et al., 2007). By the end of the twenty-first century, climate change may predict as, under low emission scenario, the average temperature would increase by $1.6-2.2^{\circ} \mathrm{C}$, the rainfall would increase by $2-6$ per cent and sea level would rise by $49-64 \mathrm{~cm}$; under average emission scenario, the average temperature would rise $2-3^{\circ} \mathrm{C}$, the rainfall goes up 2-7 per cent and sea level rises by $57-73 \mathrm{~cm}$ and under high emission scenario the average temperature rises $2-3^{\circ} \mathrm{C}$, the rainfall goes up 2-7per cent and sea level rises by $57-73 \mathrm{~cm}$ (Lorenzoni et al., 2000; McCarthy, 2001; Wassmann et al., 2004; New et al., 2011).

\subsection{The impact of climate change on livelihoods in the Red River Delta}

The delta is a large lower-section area of the Red River. It is the largest river in Northern Vietnam covering many provinces with $21,068 \mathrm{~km}^{2}$ (about 6.4 per cent) of the country's area and with a population of 19,999 (000) people (about 22.7 per cent) of the national population (GSO, 2013). The coastal zone of the Red River Delta has its high density of population, and their livelihood mainly depends on agricultural and fishery production which is highly dependent on climate change and management (Van Hue and Scott, 2008). However, in this lowland coastal zone, there is a 30 per cent of the area with an altitude of fewer than $2.5 \mathrm{~m}$ compared to the sea level, so it often suffers from the severe natural disasters, especially ocean- 
originated hazards (Nguyen et al., 2007). It is estimated that 5,000 km of the Red River Delta will affect approximately 4 million people if the sea level rises by 1 meter (Ericson et al., 2006; Hanebuth et al., 2006). The Red River delta covers four main provinces, namely, Hai Phong, Thai Binh, Nam Dinh and Ninh Binh. Nam Dinh province included in the top most populated provinces of Vietnam having population 1,110 people per $\mathrm{km}^{2}$ (Kelly-Hope et al., 2007), and people there were, directly and indirectly, involved with agriculture, mainly rice farming, aquaculture, livestock and salt production (Baulch et al., 2008). Moreover, Ninh Binh has an outstanding economic strength, including construction materials and tourism alongside the potential for agricultural development in specialized farming areas (Quý, 2013). However, in the past decade, uneven climate change impinges negative impacts of livelihoods.

Recently, many studies have focused on climate change; for instance, change in sea level by Hori et al. (2004) and Wassmann et al. (2004), rising in temperature by Thi Van and Duong Xuan Bao (2010), frequency of droughts and floods by Sano et al. (2009) and occurrence of storms by Kleinen (2007). However, very few literature are available focused on the impact of climate change on livelihoods and sustainability of vulnerable communities of Nam Dinh province Vietnam (Tran and Shaw, 2007). Much evidence of climate change in the world is available, but now it is time to focus on adaptation to climate change and build a sustainable livelihood practice for vulnerable communities. Therefore, a sustainable livelihood in coastal areas of the Red River Delta in adaptation to climate change is an urgent need.

The article deals with three main objectives:

(1) to estimate a recent trend of climate change on costal communes of Nam Dinh province;

(2) to determine the impacts of droughts, storms, floods, temperature, rise in sea level and salinity intrusion on rice and livestock productivity; and

(3) to determine perception of Nam Dinh community about the impact of climate change on their livelihoods.

\section{Research methodology}

\subsection{Selection of study sites and data collection}

The study focused on the Nam Dinh province which is a coastal region of Vietnam; it is located in the northern part of the country and part of the Red River Delta. It is in lowland coastal region, located roughly $20-21^{\circ} \mathrm{N}$ and $105-107^{\circ} \mathrm{E}$ surrounded by districts, namely, Giao Thuy, Hai Hau and Nghia Hung. It is favorable for raising livestock, fishing and agriculture (Kleinen, 2007). However, recently, Nam Dinh was included in one of the vulnerable provinces of Vietnam due to the frequency of floods, typhoons and tropical storms (Kelly and Adger, 2000). During the past quarter, it was hit by four typhoons consistently which had serious economic consequences on the welfare of inhabitants (Kleinen, 2007).

\subsection{Data collection}

For this study, cross-sectional and secondary data set was used. A cross-sectional data were collected using cluster sampling method in the year 2015 from 500 respondents to ask frequencies of occurrence of droughts, storms and floods, the rise in temperate, the rise in sea level and saline intrusion. Moreover, their perceptions of climate change impacts on their livelihoods were also recorded. A well-structured questionnaire was used to collect the data and assured them the data would only be used for research purpose without showing their identity. Those who refused to conduct interviews for some reasons were replaced with other willing respondents. 
IJCCSM

11,5

690

Figure 1.

Average annual value of agricultural and aquaculture production in Nam Dinh province (million VND per household)
A Likert scale $(1=$ Agreed; $2=$ Strongly agreed; 3 = Neither agreed or disagreed; $4=$ Strongly disagreed; 5 = Disagreed) was used to estimate the perception level of local communities about the impact of climate change on livelihood. While the secondary data were collected from the statistical yearbook of General Statistics Office of Vietnam (GSO) (2016). The data were collected on the recent trend of climatic changes such as droughts, storms, floods and temperature. In addition, information of livelihood such as rice production, livestock, aquaculture and salt production were also collected. For empirical analysis, a Cobb-Douglas (CD) production function was used to estimate the impact of climate change on livelihoods. The general functional form of $\mathrm{CD}$ production function may represent as:

$$
Y_{\mathrm{i}}=\beta_{0} X_{j}^{\beta_{j} e_{i}} \quad i=1,2, \ldots, 500
$$

where $Y_{\mathrm{i}}$ is rice production $(\mathrm{kg} / \mathrm{ha})$ and livestock (lire/farm) of $i$ th household, $X_{i j}$ is the vector of $i$ th household and $j$ is used for climatic variables (droughts, flood storms, rise in temperature, rise in sea level and saline intrusion), $\beta_{0}$ is constant, $\beta_{j}$ indicates the coefficients of climatic change variables need to be estimated and $e_{i}$ is the error term assumed that it is normally distributed with zero mean value and constant variance (Hatirli et al., 2005). By taking natural $\log (\ln )$ on both sides of above equation (1) to get the direct elasticities of unknown parameters:

$$
\ln Y_{i}=\beta_{0}+\beta_{i} \ln X_{i}+\ln e_{i} i=1,2, \ldots, 500
$$

For reliability of the data and functions, we used some statistical tests such as variance inflation factor to test multicollinearity and Durban-Watson (DW) test to check autocorrelation and independent errors. However, no multicollinearity and autocorrelation were found.

\section{Results and discussions}

3.1 Value contribution of agriculture and aquaculture and climate change impacts on communes of Nam Dinh province

3.1.1 A recent trend of household livelihoods contribution. Figure 1 illustrates an average value of agricultural production (food and cash crops) of Nam Dinh province was substantially increased by 63.3per cent from 2008 to 2010; however, from 2010 to 2016, it

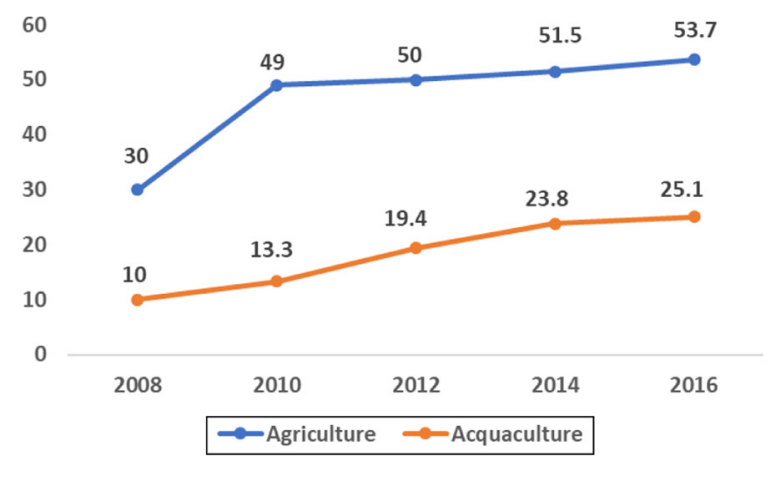

Source: NamDinh statistical office (2016) 
was only increased by 9.5 per cent because of huge variation of climate change among this period decreased the productivity of major crops (McElwee, 2012; Meyfroidt et al., 2013; Hawkins et al., 2010). On the other hand, a substantial increase about 58 per cent has found in the value of aquaculture; however, only 5.4 per cent increase is found from 2014 to 2016 due to the frequent occurrence of floods and rise in sea level. This trend implies that livelihood is significantly suffered due to variation in climate change (Morton, 2007).

3.1.2 A comparative analysis of climate change between 2010 and 2015. Further, a comparations climate change statistics between 2010 and 2015 about climate change in all communes of Vietnam. Results depict that compared with 2010 (2.9 per year), droughts more frequently occurred in all communes of Nam Dinh province in 2015 (3.2 per year), and this caused a huge devastating impact on the livelihood of local communities (Figure 2). The similar trend of change in droughts was found by other workers, for example, Shaw (2006) also found increased in the frequency of droughts in different parts of Vietnam.

On the other hand, it is estimated that overall the frequency floods and storms occurrence remained higher in 2015 in all communes than 2010 (Figure 3). All this imply that a severe change has noted in climate in the study area.

\subsection{Impact of climate change on livelihood}

In the next step, we used CD model for estimating the impact of climate change on livelihoods sources (Adger, 1999; Allison et al., 2009). The results showed that frequency of

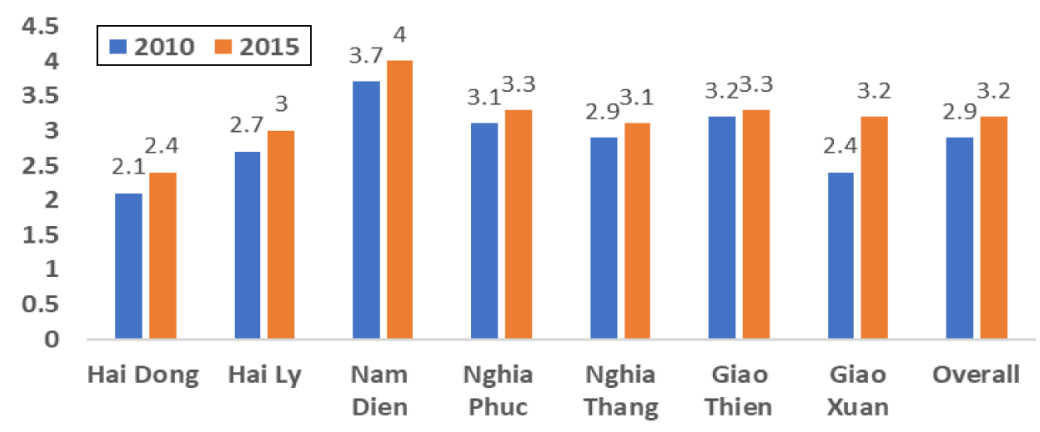

Figure 2.

Frequency of droughts occurrence between 2010 and 2015

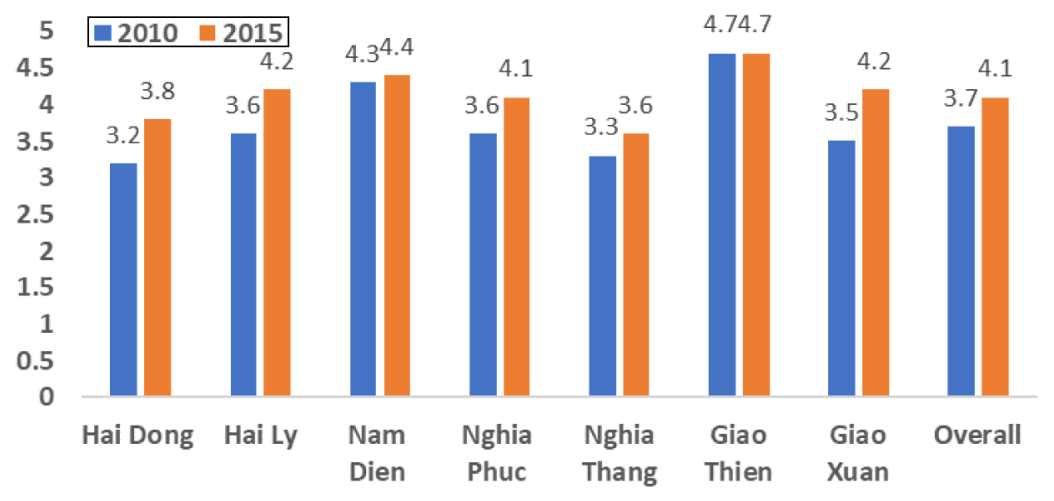

Figure 3.

Frequency of floods and storms occurrence between 2010 and 2015 
IJCCSM 11,5

\section{2}

Table I.

Climate change affects livelihood resources of Nam Dinh province (results of log-log regression models) droughts occurrence adversely impacted on rice productivity; it is satirically significant at $p<0.5$, and this implies that 1 per cent increase in drought caused 0.2 per cent decrease in rice productivity. Similar results have found many researchers; for instance, Otte et al. (2004) also found crop productivity was decreased due to frequently occurring of droughts. Flood storms are highly significant at $p<0.01$; its negative value depicts that 1 per cent increase in frequency of flood storm resulted in 0.32 per cent decrease in rice productivity. Similarly, rise in sea level is statistically significant at $p<0.1$; rice productivity was increased by 0.16 per cent with 1 per cent increase in sea level. Salinity intrusion also significantly associated with rice productivity, and this implies that with 1 per cent increase in salinity intrusion, rice productivity decreased by 0.28 per cent. On the other hand, frequency of flood storm is highly significant at $p<0.1$; it means that livestock productivity decreased by 0.03 per cent with 1 per cent increase in frequency of flood storms. For the validity of model, DW test was applied, and no autocorrelation in each model was found because every model has DW test value more than 1.9. Moreover, the models were tested for multicollinearity, and those exogenous variables found mutual relationships were excluded from the regression models; finally, the models used without the problem of multicollinearity problem. The coefficient of determination $R^{2}$ of regression models is more 0.70 for each regression model (Table I).

\subsection{Effects of climate change on household livelihood outcomes - a perception of local community}

A Likert scale was used to ask the perceptions from the local community of Nam Dinh province about the impact of climate change on livelihood; results are reported in Table II. Farmers were asked about the impact of droughts, and most of them were strongly agreed that frequent occurrence of droughts negatively impacted on rice production and animal husbandry. These results are similar to our previous findings in Table I. All of them were strongly agreed that floods were impacted by income-producing activities, including rice farming and animal. The community response was indifference

\begin{tabular}{lcc}
\hline Climate change & Rice productivity & Livestock productivity \\
\hline Drought & $-0.2^{* * *}(0.098)$ & $-0.03(0.089)$ \\
Flood storm & $-0.32^{* * *}(0.09)$ & $-0.24 * * *(0.08)$ \\
Rising temperature & $0.13(0.10)$ & $0.34(0.09)$ \\
Rise in sea level & $0.16^{*}(0.09)$ & $0.03(0.08)$ \\
Salinity intrusion & $-0.28^{* * * *(0.09)}$ & $0.02(0.08)$ \\
$R^{2}$ & 0.70 & 0.72 \\
DW test & 1.9 & 2.1
\end{tabular}

Notes: Standard errors are in parenthesis; ***, **and *represented significant level at 1, 5 and 10\%, respectively

\section{Table II.}

Perceptions Nam Dinh community about the impact of climate change (results of Likert scale)

\begin{tabular}{lccccc}
\hline $\begin{array}{l}\text { Climate change/income } \\
\text { generation activities }\end{array}$ & Drought & Flood storm & $\begin{array}{c}\text { Rise in } \\
\text { temperature }\end{array}$ & $\begin{array}{c}\text { Rise in sea } \\
\text { level }\end{array}$ & $\begin{array}{c}\text { Salinity } \\
\text { intrusion }\end{array}$ \\
\hline Rice productivity & 2 & 1.8 & 2.6 & 2.7 & 2.8 \\
Livestock productivity & 2.2 & 2 & 2.7 & 2.9 & 2.9
\end{tabular}

Source: Cross-sectional data collected from Nam Dinh Province (2015) 
about the impact of the rise in temperature, sea level and salinity intrusion on income generation activities.

\section{Conclusion and policy implications}

Based on study results, it is concluded that although the value of agriculture and aquaculture increased from 2008 to 2012, a frequent increase in droughts, floods and saline intrusion negatively and significantly impacted on rice productivity, while livestock productivity was also significantly decreased due to flood storms. The study results suggest a government support to adopt some policy measures in the context of climate change to achieve objective of sustainable livelihoods for coastal communities in the Red River Delta.

\section{References}

Adger, W.N. (1999), "Social vulnerability to climate change and extremes in coastal Vietnam", World Development, Vol. 27 No. 2, pp. 249-269.

Adger, W.N., Hughes, T.P., Folke, C., Carpenter, S.R. and Rockström, J. (2005), "Social-ecological resilience to coastal disasters", Science (New York, N.Y.), Vol. 309 No. 5737, pp. 1036-1039.

Allison, E.H. and Horemans, B. (2006), "Putting the principles of the sustainable livelihoods approach into fisheries development policy and practice", Marine Policy, Vol. 30 No. 6, pp. 757-766.

Allison, E.H., Perry, A.L., Badjeck, M.C., Neil Adger, W., Brown, K., Conway, D., Halls, A.S., Pilling, G. M., Reynolds, J.D., Andrew, N.L. and Dulvy, N.K. (2009), "Vulnerability of national economies to the impacts of climate change on fisheries", Fish and Fisheries, Vol. 10 No. 2, pp. 173-196.

Arouri, M., Nguyen, C. and Youssef, A.B. (2015), "Natural disasters, household welfare, and resilience: evidence from rural Vietnam”, World Development, Vol. 70, pp. 59-77.

Baulch, B., Hansen, H., Trung, L.D. and Tam, T.N.M. (2008), "The spatial integration of paddy markets in Vietnam”, Journal of Agricultural Economics, Vol. 59 No. 2, pp. 271-295.

Cai, Y., Li, L., Elahi, E. and Qiu, Y. (2018), "Selection of policies on typhoon and rainstorm disasters in China: a content analysis perspective", Sustainability, Vol. 10 No. 2, p. 387.

Chaudhry, P. and Ruysschaert, G. (2007), Climate Change and Human Development in Viet Nam: A Case Study for the Human Development Report 2007/2008, UNDP, Hanoi.

Ericson, J.P., Vörösmarty, C.J., Dingman, S.L., Ward, L.G. and Meybeck, M. (2006), "Effective sea-level rise and deltas: causes of change and human dimension implications", Global and Planetary Change, Vol. 50 Nos 1/2, pp. 63-82.

General Statistics Office of Vietnam (GSO) (2016), Statistical Year Book, Vietnam Statistics Publishing House, Hanoi.

Guha-Sapir, D., Hargitt, D. and Hoyois, P. (2004), Thirty Years of Natural Disasters 1974-2003: The Numbers, Presses Univ. de Louvain.

Hanebuth, T.J., Saito, Y., Tanabe, S., Vu, Q.L. and Ngo, Q.T. (2006), "Sea levels during late marine isotope stage 3 (or older?) reported from the red river Delta (Northern vietnam) and adjacent regions", Quaternary International, Vol. 145-146, pp. 119-134.

Hanh, P.T.T. and Furukawa, M. (2007), "Impact of sea level rise on coastal zone of Vietnam”, BulletinCollege of Science University of the Ryukyus, Vol. 84, p. 45.

Hatirli, S.A., Ozkan, B. and Fert, C. (2005), "An econometric analysis of energy input-output in Turkish agriculture”, Renewable and Sustainable Energy Reviews, Vol. 9 No. 6, pp. 608-623.

Hawkins, S., Robertson, S., Thu Thuy, P., Xuan To, P., McNally, R., Van Cuong, C., Dart, P., Xuan Phuong, P., Brown, S., Vu, N. and Duc Tu, N. (2010), Roots in the Water: Legal Frameworks for Mangrove PES in Vietnam. 
IJCCSM 11,5

Hori, K., Tanabe, S., Saito, Y., Haruyama, S., Nguyen, V. and Kitamura, A. (2004), "Delta initiation and Holocene sea-level change: example from the song Hong (red river) Delta, Vietnam", Sedimentary Geology, Vol. 164 Nos 3/4, pp. 237-249.

Huong, H.T.L. and Pathirana, A. (2013), "Urbanization and climate change impacts on future urban flooding in Can Tho city, Vietnam”, Hydrology and Earth System Sciences, Vol. 17 No. 1, pp. 379-394.

Kelly, P.M. and Adger, W.N. (2000), "Theory and practice in assessing vulnerability to climate change and facilitating adaptation", Climatic Change, Vol. 47 No. 4, pp. 325-352.

Kelly-Hope, L.A., Alonso, W.J., Thiem, V.D., Anh, D.D., Do, Gia, C.A.N.H., Lee, H., Smith, D.L. and Miller, M.A. (2007), "Geographical distribution and risk factors associated with enteric diseases in Vietnam”, Environmental Health Perspectives, Vol. 116 No. 1, pp. 706-712.

Kleinen, J. (2007), "Historical perspectives on typhoons and tropical storms in the natural and socio-economic system of Nam Dinh (vietnam)", Journal of Asian Earth Sciences, Vol. 29 No. 4, pp. 523-531.

Lorenzoni, I., Jordan, A., Hulme, M., Turner, R.K. and O'Riordan, T. (2000), “A co-evolutionary approach to climate change impact assessment: Part I. Integrating socio-economic and climate change scenarios", Global Environmental Change, Vol. 10 No. 1, pp. 57-68.

McCarthy, J.J. (Ed.) (2001), Climate Change 2001: Impacts, Adaptation, and Vulnerability: contribution of Working Group II to the Third Assessment Report of the Intergovernmental Panel on Climate Change, Cambridge University Press, Cambridge.

McElwee, P.D. (2012), "Payments for environmental services as neoliberal market-based Forest conservation in Vietnam: Panacea or problem?”, Geoforum, Vol. 43 No. 3, pp. 412-426.

Mai, V.T., Hessel, R., Van Keulen, H., Ritsema, C. and Roetter, R.P. (2007), "Simulation of soil erosion in Quan Dinh watershed in tam Duong district, North Vietnam", Soil Erosion and Nitrogen Leaching in Northern Vietnam: Experimentation and Modelling, p. 35.

Meyfroidt, P., Vu, T.P. and Hoang, V.A. (2013), "Trajectories of deforestation, coffee expansion and displacement of shifting cultivation in the central highlands of Vietnam", Global Environmental Change, Vol. 23 No. 5, pp. 1187-1198.

Morton, J.F. (2007), "The impact of climate change on smallholder and subsistence agriculture", Proceedings of the National Academy of Sciences, Vol. 104 No. 50, pp. 19680-19685.

NamDinh statistical (2016), “Agriculture”, Aquaculture 2016, available at: http://namdinh.gso.gov.vn/ default.aspx (accessed 12 February, 2018).

Navrud, S., Huu Tuan, T. and Duc Tinh, B. (2012), "Estimating the welfare loss to households from natural disasters in developing countries: a contingent valuation study of flooding in Vietnam", Global Health Action, Vol. 5 No. 1, p. 17609.

New, M., Liverman, D., Schroder, H. and Anderson, K. (2011), "Four degrees and beyond: the potential for a global temperature increase of four degrees and its implications".

Nguyen, D.Q., Renwick, J. and McGregor, J. (2014), "Variations of surface temperature and rainfall in vietnam from 1971 to 2010", International Journal of Climatology, Vol. 34 No. 1, pp. 249-264.

Nguyen, H.N., Vu, K.T. and Nguyen, X.N. (2007), "Flooding in Mekong River Delta, Viet Nam”, Human development report, 2008, p. 23.

Noy, I. and Vu, T.B. (2010), "The economics of natural disasters in a developing country: the case of Vietnam", Journal of Asian Economics, Vol. 21 No. 4, pp. 345-354.

Otte, M.J., Nugent, R. and McLeod, A. (2004), Transboundary Animal Diseases: Assessment of SocioEconomic Impacts and Institutional Responses, Food and Agriculture Organization (FAO), Rome.

Quý, H.S. (2013), “The red river Delta region in regional culture studies”, Social Sciences Information Review, Vol. 5 No. 4, pp. 3-12.

Sano, M., Buckley, B.M. and Sweda, T. (2009), "Tree-ring based hydroclimate reconstruction over Northern Vietnam from Fokienia Hodginsii: eighteenth century mega-drought and tropical pacific influence", Climate Dynamics, Vol. 33 Nos 2/3, p. 331. 
Shaw, R. (2006), "Community-based climate change adaptation in Vietnam: inter-linkages of environment, disaster, and human security", Multiple Dimensions of Global Environmental Change, pp. 521-547.

Thi Van, T.R.A.N. and Duong Xuan Bao, H.A. (2010), "Study of the impact of urban development on surface temperature using remote sensing in ho chi minh city, Southern Vietnam", Geographical Research, Vol. 48 No. 1, pp. 86-96.

Tran, P. and Shaw, R. (2007), "Towards an integrated approach of disaster and environment management: a case study of Thua Thien hue province, central Viet Nam", Environmental Hazards, Vol. 7 No. 4, pp. 271-282.

Van Hue, L.T. and Scott, S. (2008), "Coastal livelihood transitions: socio-economic consequences of changing mangrove Forest management and land allocation in a commune of Central Vietnam", Geographical Research, Vol. 46 No. 1, pp. 62-73.

Vien, T.D. (2011), "Climate change and its impact on agriculture in Vietnam", Hanoi University of Agriculture, J. Issaas, Vol. 17 No. 1, pp. 17-21.

Wassmann, R., Hien, N.X., Hoanh, C.T. and Tuong, T.P. (2004), "Sea level rise affecting the Vietnamese Mekong Delta: water elevation in the flood season and implications for rice production", Climatic Change, Vol. 66 Nos 1/2, pp. 89-107.

\section{Further reading}

Duong, C.T., Nguyen, T.H., Hoang, T.T.H., Nguyen, V.V., Do, T.M.N. and Detels, R. (2008), "Sexual risk and bridging behaviors among young people in Hai Phong, Vietnam", AIDS and Behavior, Vol. 12 No. 4, pp. 643-651.

Hien, P.D., Bac, V.T., Tham, H.C., Nhan, D.D. and Vinh, L.D. (2002), "Influence of meteorological conditions on PM2. 5 and PM2. 5- 10 concentrations during the monsoon season in Hanoi, Vietnam", Atmospheric Environment, Vol. 36 No. 21, pp. 3473-3484.

Weiss, J. (2009), “The economics of climate change in Southeast Asia: a regional review”.

\section{Author affiliations}

Thi Kieu Van Tran, Department of Economics and Management, China Agricultural University, Beijing, China

Ehsan Elahi, School of Business, Nanjing University of Information Science and Technology, Nanjing, China

Liqin Zhang, Department of Economics and Management, China Agricultural University, Beijing, China

Habibullah Magsi, Department of Agricultural Economics, Sindh Agriculture University, Tandojam, Pakistan

Quang Trung Pham, Central Institute for Economic Management, Hanoi, Vietnam, and

Tuan Minh Hoang, School of Economics and Management, Beijing Forestry University, Beijing, China

\section{Corresponding authors}

Liqin Zhang can be contacted at: liq-zh@263.net and Ehsan Elahi can be contacted at: ehsanelahi@ nuist.edu.cn

For instructions on how to order reprints of this article, please visit our website:

www.emeraldgrouppublishing.com/licensing/reprints.htm

Or contact us for further details: permissions@emeraldinsight.com 